Language Change in the Wake of Empire 


\title{
Linguistic Studies in Ancient West Semitic
}

\author{
edited by
}

\section{Cynthia L. Miller-Naudé and Jacobus A. Naudé}

The series Linguistic Studies in Ancient West Semitic is devoted to the ancient West Semitic languages, including Hebrew, Aramaic, Ugaritic, and their near congeners. It includes monographs, collections of essays, and text editions informed by the approaches of linguistic science. The material studied will span from the earliest texts to the rise of Islam.

1. The Verbless Clause in Biblical Hebrew: Linguistic Approaches, edited by Cynthia L. Miller

2. Phonology and Morphology of Biblical Hebrew: An Introduction, by Joshua Blau

3. A Manual of Ugaritic, by Pierre Bordreuil and Dennis Pardee

4. Word Order in the Biblical Hebrew Finite Clause: A Syntactic and Pragmatic Analysis of Preposing, by Adina Moshavi

5. Oath Formulas in Biblical Hebrew, by Blane Conklin

6. Biblical Hebrew Grammar Visualized, by Francis I. Andersen and A. Dean Forbes

7. Time and the Biblical Hebrew Verb: The Expression of Tense, Aspect, and Modality in Biblical Hebrew, by John A. Cook

8. Diachrony in Biblical Hebrew, edited by Cynthia L. Miller-Naudé and Ziony Zevit

9. The Syntax of Volitives in Biblical Hebrew and Amarna Canaanite Prose, by Hélène Dallaire

10. The Relative Clause in Biblical Hebrew, by Robert D. Holmstedt

11. Language Change in the Wake of Empire: Syriac in Its Greco-Roman Context, by Aaron Michael Butts 


\section{Language Change in the Wake of Empire}

Syriac in Its Greco-Roman Context

Aaron Michael Butts

Winona Lake, Indiana

EISENBRAUNS

2016 
Copyright (C) 2016 Eisenbrauns

All rights reserved.

Printed in the United States of America.

www.eisenbrauns.com

\section{Library of Congress Cataloging-in-Publication Data}

Names: Butts, Aaron Michael, author.

Title: Language change in the wake of empire : Syriac in its GrecoRoman context / Aaron Michael Butts.

Description: Winona Lake, Indiana: Eisenbrauns, 2016. I Series: Linguistic studies in Ancient West Semitic ; 11 I Revision of author's thesis, University of Chicago, 2013. I Includes bibliographical references, appendixes, and indexes. I Description based on print version record and CIP data provided by publisher; resource not viewed.

Identifiers: LCCN 2015050107 (print) I LCCN 2015047546 (ebook) | ISBN 9781575064222 (paperback) I ISBN 9781575064215 (hardback : alk. paper)

Subjects: LCSH: Greek language-Influence on Syriac. I Syriac language-History. I Languages in contact.

Classification: LCC PJ5415 (print) | LCC PJ5415 .B88 2016 (ebook) | DDC 492/.32481—dc23

LC record available at http://lccn.loc.gov/2015050107

The paper used in this publication meets the minimum requirements of the American National Standard for Information Sciences-Permanence of Paper for Printed Library Materials. ANSI Z39.48-1984.@TM 
For Sebastian Brock 
